\title{
Pre-slaughter stress affects cortisol and adrenocorticotropic hormone levels in the blood of animals
}

\author{
Stepan Grabovskyi ${ }^{1}$, \\ Oleksandra Grabovska², \\ Viktoriia Havryliak ${ }^{3}$, \\ Liliia Kalachniuk,
}

\author{
Alla Velyka ${ }^{5}$ \\ ${ }^{1}$ Lviv National University \\ of Veterinary Medicine \\ and Biotechnologies \\ named after S. Z. Gzhytskyi, \\ 50 Pekarska St., \\ Lviv 79010, Ukraine \\ ${ }^{2}$ Institute of Animal Biology NAAS, \\ V. Stus St., 38, Lviv 79034, Ukraine \\ ${ }^{3}$ Lviv Polytechnic National University, \\ 3/4, Svyatyi Yuriy Sq., \\ Lviv 7901, Ukraine \\ ${ }^{4}$ National University of Life \\ and Environmental Sciences of Ukraine, \\ 15 Heroiv Oborony St., Kyiv 03041, Ukraine \\ ${ }^{5}$ Higher State Educational Establishment \\ "Bucovinian State Medical University", \\ 2 Teatralna Sq., Chernivtsi 58002, Ukraine
}

An increase in the cortisol and adrenocorticotropic hormone (ACTH) concentration in blood is observed in various diseases, and especially under stress conditions, which explains why they are referred to as stress hormones. The paper presents the results of measuring the cortisol level in the blood of laboratory animals (rats), of the ACTH level in the blood of bulls, and the cortisol and ACTH level in the blood of the boars under the pre-slaughter stress of these animals. Depending on the priority of animal removal from the cage, the cortisol level increased by nearly 1.5 times $(P<0.01)$ in rats and by nearly five times $(P<0.05)$ in animals that were removed from each cage last. The ACTH concentration in the blood plasma of bulls before setting a study (preparatory period) was 1.3 times lower $(P \leq 0.01)$ compared with its content in the blood plasma of the bulls immediately before their transportation to a slaughterhouse. The changes in the cortisol and ACTH content in the blood plasma of the boars were similar. The results of our studies could be of interest in correcting hormonal adaptation to negative consequences of stress effect during the pre-slaughter period in animals used for industrial production of meat.

Keywords: pre-slaughter stress, stress hormones, rats, calves, boars

\footnotetext{
*Corresponding author. Email: grbss@ukr.net
} 


\section{INTRODUCTION}

Stress is a multifactorial phenomenon that affects the functioning of the organism. The human immune system is the most sensitive to the action of stress (Segerstrom, Miller, 2004), which leads to a sharp decrease in the body's resistance to infections and cancer. Stress in livestock and pigs, in particular, leads to economic losses and animal products quality impairment (Dokmanović et al., 2014; Kim et al., 2014; Rocha et al., 2013). The duration of the process of transportation and unloading of animals, which is accompanied by skin damage in animals, affects the biochemical parameters and the qualitative characteristics of their meat (Ferguson, Warner, 2008; Wesoly et al., 2015).

The literature on the impact of stressful situations on animal behaviour is somewhat contradictory but most of the authors (Slocombe, Zuberbuhler, 2005; Pica, Mitani, 2005; Zhukov, 2014) tend to believe that, basically, the reaction of struggle (aggression) or escape (an active reaction), and the stupor reaction, concealment (passive reaction) are behaviour strategies. After a thorough study conducted on cats, Cannon (1927) described the active form of the response to acute stress in critical situations as an escape or fight (Cannon, 1927). He believes that in the preparation and implementation of these behaviour forms, the function of the sympathetic nervous system and the medulla of the adrenal glands are of primary importance. There is another type of behavioural reactions observed in threatened animals that is called "tailing off". Gray (1971) describes the stupor as a "silent tense immobility". There are different views on whether to consider fading an active or passive type reaction (Panchenko, 2003). Certain types of reaction (active or passive) dominate among different species of animals.

However, none of these forms of reaction to stress surpasses the animal's condition before slaughter when the animal feels danger and is in a hopeless situation. In our opinion, such a condition of an animal leads to metabolic changes in the whole organism.
A change in hormone concentration may be associated with the processes of their formation, activation, or inhibition of certain substances and, most likely, the influence of various stress reactions. Hormones affect the synthesis of messenger RNA, which in turn leads to the biosynthesis of enzyme proteins. We performed a model experiment on rats (Grabovskyi, 2014) to determine the parameters of cellular immunity and concentration of the stress hormone (cortisol) as some authors described in their studies (Gibson, Norman, 1993). The difference was that we took only the pre-slaughter stress into account.

As some authors point out, manipulations with laboratory animals are accompanied by stress and lead to significant changes in physiological parameters, such as the heart rate, the blood pressure, and behavioural responses. Changes in concentration of corticosterone, glucose, the growth hormone or prolactin in the blood of these animals were observed. However, these changes were short-lived - $30 \mathrm{~min}$ utes or slightly longer (Balcombe et al., 2004).

The information on the influence of the preslaughter stress on animals' metabolic processes and animal body as a whole is not highlighted in the literature. Therefore, our goal was to determine the level of some stress hormones in different animals.

\section{MATERIALS AND METHODS}

Three experiments were performed.

The first experiment was conducted on white mature female Wistar rats, of 180-220 g body weight, which were kept under standard vivarium conditions with the observance of 12-hour regime of dark/light illumination at a temperature of $20-22^{\circ} \mathrm{C}$ and unlimited access to drinking water and feed. Rats were fed baled fodder standard for laboratory animals. For the experiment, 25 rats were used, five in each group. Rats of all groups were fed the standard diet. Feed material was controlled daily. The rats' blood was taken in the morning after decapitation under ether anaesthesia. The changes in the rats' blood plasma related 
to the cortisol concentration were determined depending on the alternating sequence of taking the animals from the cage (starting from the first to the fifth animal).

Each group (1-5) of five rats, taken one at a time from each of the five cages, was slaughtered in the next room so that the remaining animals could not see the slaughter procedure.

The second experiment was conducted on bulls (aged 12 months) of the Ukrainian black and white dairy breed. The animals were kept on a standard diet at the experimental farm in Komarno village (Gorodok district of Lviv region). Control over feed material was performed daily. The bulls ate complete fodder. Slaughter of the animals was carried out at lunch time. The experiment lasted for five days. The blood of the bulls was collected from the jugular vein before transportation and further slaughter of the animals.

The third experiment involved boars (aged six months) of the Duroc breed. The animals were kept on dry feed of "Lemberg-Agro" company in Lischyny village (Zydachiv district, Lviv region). The boars received only dry fodder. The animals were slaughtered at 13 oclock. The hormone content in the blood plasma of the boars was compared before and after transportation - just before the slaughter of the animals.

The blood plasma was prepared by centrifugation (1000-2000 rpm) from the whole blood stabilized by heparin. The cortisol and adrenocorticotropin (ACTH) concentration was determined in the blood plasma by the standard method.

The principle of the method is a solid enzyme-binding immunosorbent set which was created on the basis of competition. The microtiter wells were coated with monoclonal antibody against the molecules of antigen. A sample of blood plasma with the endogenous cortisol was incubated in the well with enzyme conjugate. The unbound conjugate was washed off after the incubation period. The amount of bound peroxidase was inversely proportional to the concentration of cortisol in the sample. After adding the substrate, the formed colour intensity was inversely proportional to the con- centration of cortisol in the sample (Vlizlo et al., 2012). The ACTH concentration were determined by the Set for Immuno-enzyme analysis (IEA) EIA-3647, ACTH (Adrenocorticotropic Hormone) DRG (USA). The disadvantage of the ACTH determination method is its relatively low specificity at some states; therefore, it must necessarily be supplemented by determination of the cortisol level.

During the experiment, all bioethical standards under the European Convention "On protection of vertebrate animals used for experimental and scientific purposes" (Strasbourg, 1986) and "General ethical principles of animal experimentation", approved by the First National Congress on Bioethics (Kyiv, 2001) and the principles of humanity set out in the directive of the European Community (Official Journal of the European Union, 2010) were observed. The results research were statistically processed with the software package Statistica 6.0 and Microsoft Excel for Windows XP. Probability of differences was assessed by Student t-test. Results were statistically significant at $P \leq 0.05$.

\section{RESULTS}

The results presented in Fig. 1 show the cortisol concentration in the blood plasma of rats. The data are illustrated better when viewing cortisol changes in each animal in particular. Thus, the cortisol concentration depended on the order of taking the animal out of the cage. The level of cortisol in first group of animals ranged from $34.9 \mathrm{ng} / \mathrm{ml}$ (the animal that was taken from the cage the first) to $178.9 \mathrm{ng} / \mathrm{ml}$ (the animal that was taken from the cage the last).

As can be seen from Fig. 1, cortisol concentrations increased markedly significantly, by 3.6 and 5.2 times, in animals that were taken from the cage the fourth and the fifth, respectively. These data may indicate that the animals felt stressful, especially before slaughter.

The results on the adrenocorticotropic hormone concentration in the bulls' plasma are presented in Fig. 2. It should be noted that the concentration of adrenocorticotropin before the experiment (preparatory period) was 

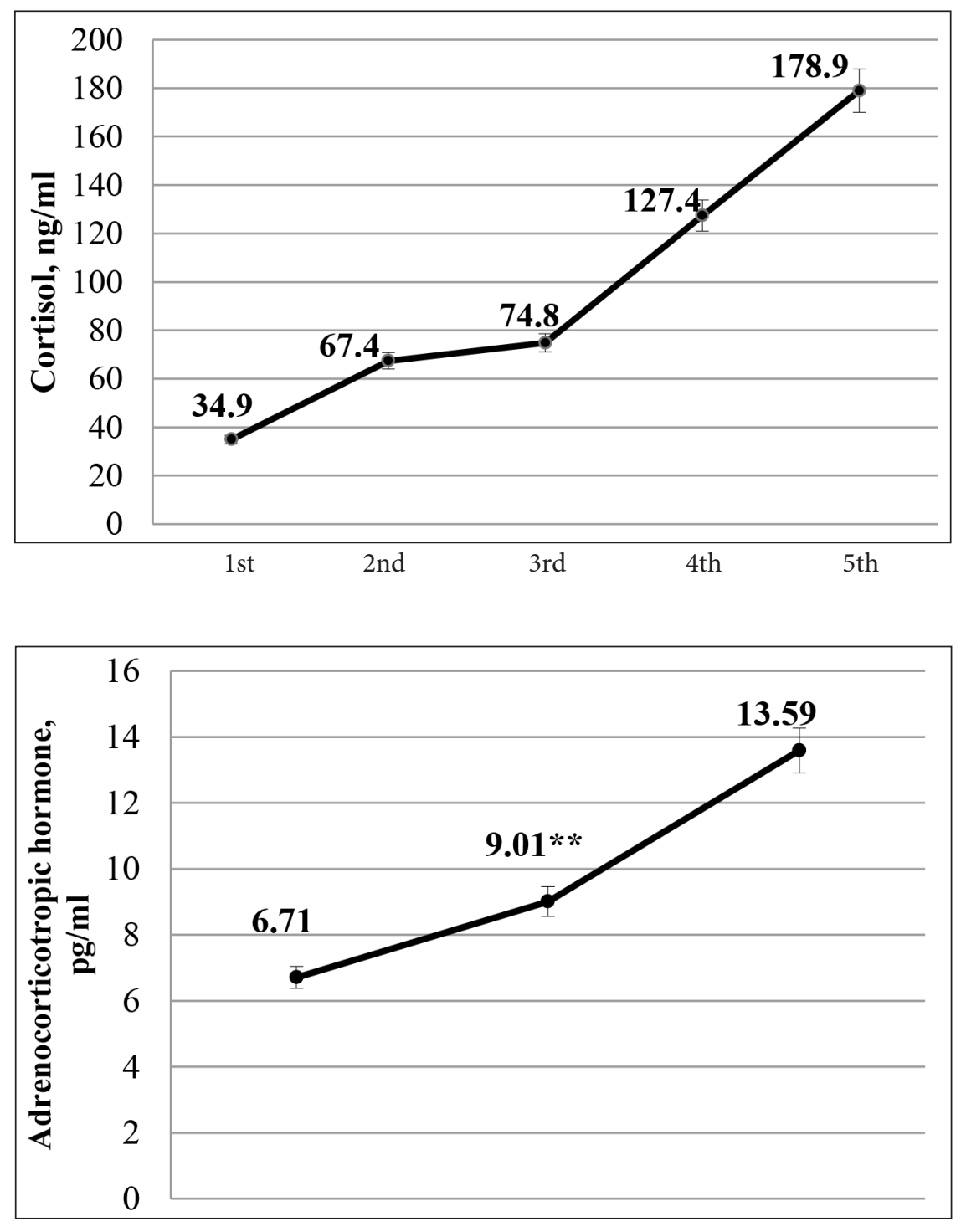

Periods: Preparatory Pre-transportation Pre-slaughter
Fig. 1. The cortisol level in the blood plasma of the rats depending on the order of their removal from the cage (1st, 2nd, $3 \mathrm{~d}, 4$ th, and 5th animal), $\mathrm{ng} / \mathrm{ml}(M \pm m, n=5)$
Fig. 2. The adrenocorticotropin level in the bulls' blood in the preparatory and pre-slaughter periods, $\mathrm{pg} / \mathrm{ml}(M \pm m$, $n=5)$

Note: A statistically significant difference between the studied periods: ${ }^{* *}-P \leq 0.01$ ).

significantly lower than the levels of this hormone before transportation and slaughter of the animals. Thus, the level of adrenocorticotropin before transportation was higher by $34 \%$ $(P \leq 0.01)$, while in the pre-slaughter period increased more than twice $(P \leq 0.01)$. Since blood samples were taken at the same time, we can assume that the bulls underwent a greater stress before transportation and slaughter compared with the animals in preparatory period.

Describing the hormone concentration in the bulls' plasma in the period before slaughtering, the level of cortisol was significantly higher, by 2.7 times $(P<0.05)$ compared to that of the animals in the pre-transportation period (Fig. 3). The cortisol concentration in the bulls' blood plasma was almost at the same level in the preparatory period and before transportation of the animals.

We determined that the cortisol and adrenocorticotropic hormone level in the boars' blood plasma increased after transportation - before the slaughtering period in comparison with their level at the pre-transportation period (Fig. 4).

Our results showed that the period before and after transportation had a significant effect on the concentration of hormones in boars (Fig. 3). It was observed that the cortisol level in 


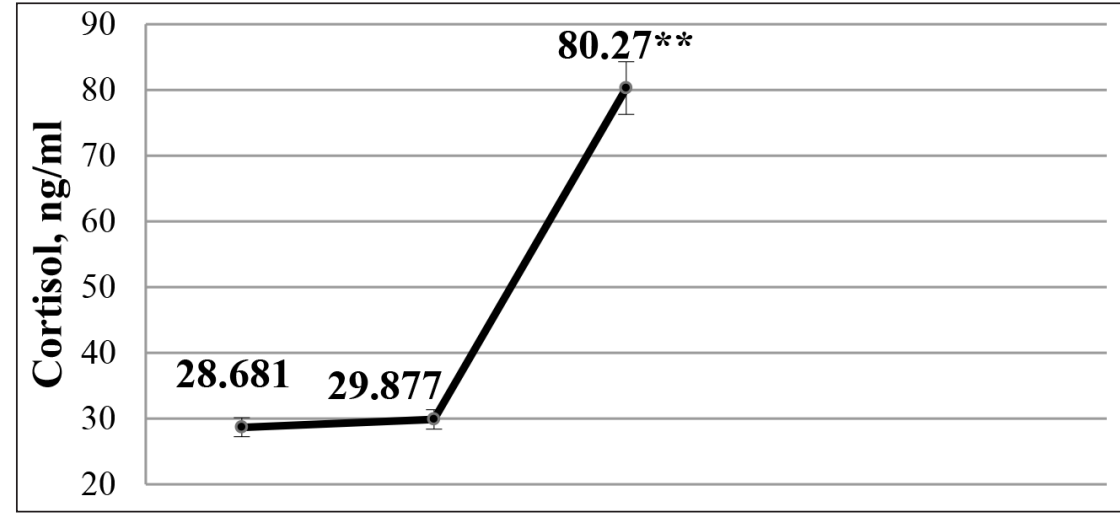

Note: A statistically significant difference between the studied periods ${ }^{\star \star}-P \leq 0.05$.
Fig. 3. The cortisol level in the bulls' blood in the preparatory and pre-slaughter periods, $\mathrm{ng} / \mathrm{ml}(M \pm m$, $n=5)$

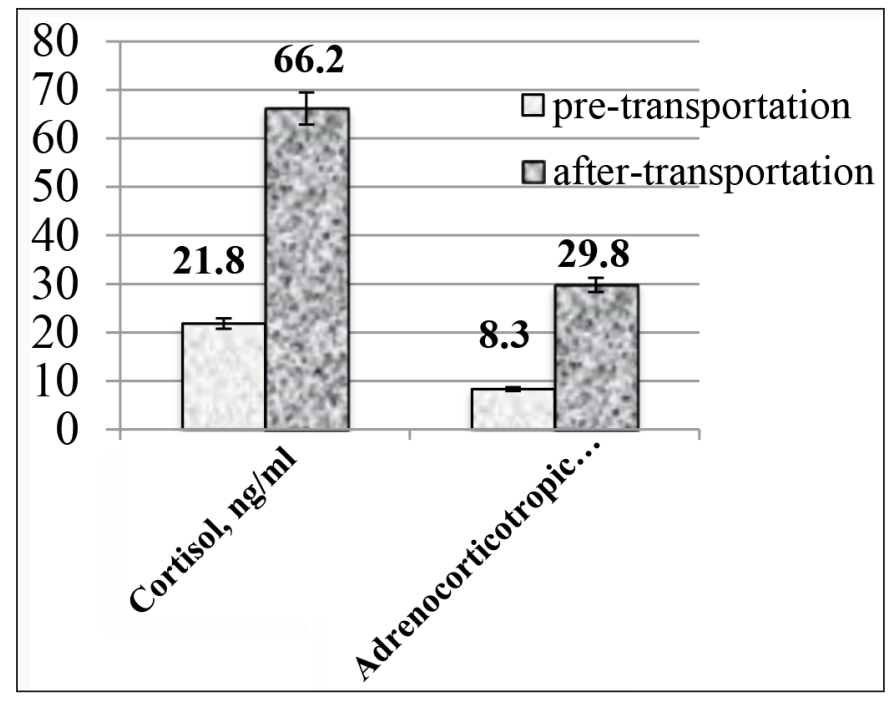

Fig. 4. The hormone level in the boars' blood plasma at pre- and post-transportation period $(M \pm m, n=5)$ the boars' blood increased three times $(P \leq 0.05)$ after transportation. Similar changes were found for the adrenocorticotropic hormone. Thus, the adrenocorticotropin concentration was 3.5 times higher $(P \leq 0.05)$ in the boars before slaughter.

The obtained data indicate that after transportation and before slaughter the animals are under stress: adrenocorticotropic hormone and cortisol concentrations are quite high at lunchtime.

\section{DISCUSSION}

It is known that acute stress is observed in animals during transportation and before slaughter procedures, but this does not mean that these operations can not be improved. The use of reliable indicators to assess the physiological and psychological state of animals makes it possible to better understand the stress caused by the pre-slaughter state (Costa, 2009). Knowledge of the physiological, behavioural, and ecological needs of animals makes it possible to develop preventive measures for reducing stress in animals.

An increased blood serum cortisol level is an indicator of the stress response in animals resulting from the stimulation of the sympathetic and parasympathetic nervous system and the hypothalamic-pituitary-adrenal axis. The above stimulates the adrenergic system to produce catecholamines and enhances secretion of steroid hormones, mainly cortisol, from the adrenal cortex (Agnes et al., 1990; Zavy et al., 1992; Śmiecińska et al., 2011). 
The obtained data show that animals display signs of stress during transportation and before slaughter. It was found that the cortisol level changed significantly in the rats' blood plasma depending on the sequence of animal removal from the cage (from the first to the fifth animal). The cortisol was significantly higher in the rats that were removed from cages the last.

In our previous studies (Grabovskyi, 2014), we used analysis of variance for the comparison of cortisol concentration in the rats' blood from animals of the control and experimental groups for the evaluation of the impact of stress effects on the level of this hormone and the density correlation. During slaughtering, rats were picked up from the cage in the order from the first to last one. The mean value, variance, standard deviation, quadratic coefficient of variation and the average of intradispersion intergroup variance of cortisol level in the blood of animals, and the correlation ratio were calculated for each of the experimental groups, the control group, and, in general, for all experimental animals (Gerasimenko et al., 2000). Our data showed that taking into account the quadratic coefficient of variation, which become smaller from the first group to control, the following conclusions about certain regularity can be made: from the first animal in the cage to the last one, it traces not only the growth of the concentration index, but the homogeneity of variance increases with each group. This implies that the animal feels stressful, especially before slaughter.

It is well known that glucocorticoids affect practically all systems of an organism. Biologically active glucocorticoid is cortisol, which accounts for $80 \%$, other corticoids $-20 \%$ in order to reduce their activity, corticosterone, 11-deoxycortisol and 11-deoxycorticosterone. Cortisol is the main corticosteroid, which controls the secretion of corticoliberin and the adrenocorticotropic hormone. The level of cortisol has distinct diurnal variations: the highest level was observed in the morning. There is a considerable amount of data about the changes in the concentrations of cortisol during the day (Price et al., 1983; Mormont, Waterhouse, 2002; Rich et al., 2005; Haus, 2007).

It was established that the type of the stressor can determine quantitative differences in the reaction of the central nervous system and the centres of the hypothalamicpituitary-adrenal axis. Thus, compared with Wistar line rats, the primary immune response to the introduction of sheep red blood cells after stress exposure was significantly higher in August line rats with higher basal and poststress levels of corticosterone in the blood. This means that in the rats (August line), immune system resistance to stress damage was higher (Frolov et al., 1985).

Our results show that the level of adrenocorticotropin in the bulls' blood before and after transportation was probably higher compared to the preparatory period. Nanni L. Costa (2009) described in detail the biochemical changes in the organism of farm animals during transportation and before slaughter (Costa, 2009). He also noted the loss of live weight and carcass yield of animals in these conditions.

The cortisol and ACTH level in boars also increased before slaughter. Similar results were observed in the study of Śmiecińska et al. (2011). The author believes that a significant increase in creatine kinase activity (more than five-fold) and cortisol levels in blood samples collected after transportation (during carcass bleeding) in comparison with blood samples obtained before transportation suggests that pre-slaughter handling operations induced an intensive stress response in the investigated animals (Śmiecińska et al., 2011).

Interesting results were presented by Gispert et al. (2000), who showed that animals slaughtered immediately after transportation are characterised by higher serum cortisol levels in blood samples than pigs slaughtered after a 24-hour rest period. These data suggest that rest before slaughter restores the body's physiological balance and alleviates the stress induced by pre-slaughter handling (Gispert et al., 2000). 
On the other hand, pigs are characterized by various resistances to stress and ease of adaptation. Linkovskyy points to genetic factors in response to stress impact (Linkowski et al., 1993).

Hormonal changes in rabbits were observed in a different stress type that was indicated on a negative influence of the stress factor on their body. In particular, during the transportation of animals, an excess amount of catecholamine was released into the blood that led to a deviation of the microcirculation, general metabolism, activity of hemopoietic organs, and immunogenesis with the migration of lymphoid cells (Ibragimova, Ismagilova, 2013).

Analysis of the biochemical parameters of the blood of rabbits showed a negative impact of stress before slaughter on the adaptive mechanisms of their bodies. However, the rabbits treated with the extract of spleen as the antistressor and immunomodulator, show lower cortisol levels compared to the control group animals (Grabovskyi, Grabovska, 2015).

A decrease in the cortisol concentration in the blood plasma of broiler chicken of experimental groups under stress coincides with some research (Malisch et al., 2010). Some authors (Azarova et al., 2013) have noted no changes, while others indicate that those changes require several hours or a few days for stress-factor action (Marti et al., 1997; Tinnikov, 1999, Lynn et al., 2003). It is likely that acute stress reaction-response may relate to physiological or environmental conditions and in particular before slaughtering stress.

A decrease in the concentration of free cortisol in the blood plasma of chickens of the experimental group was determined, possibly associated with an increase in the content of the globulin fraction. These changes can be explained by the feeding of spleen extract obtained using ultrasound. Similar results were obtained in studies on rats during stress (forced swimming). The authors reported an extremely dynamic role globulin, which regulates the concentration of glucocorticoids under acute stress conditions (Qian et al., 2011; Minni et al., 2012).
We propose expanding the generally accepted views on the reaction to stress (struggle, flight, or fading) with yet another reaction - stress before slaughter, when the animal feels it has no chances of life and which, in our opinion, leads to metabolic changes at the level of the whole body (Stahl, 2008; Kuzmenko et al., 2010).

\section{CONCLUSIONS}

It can be concluded that stress related to transportation and pre-slaughter procedures in animals has the strongest effects on the levels of cortisol and adrenocortocotropin. In our study, the concentrations of these stress hormones increased immediately before the transportation of the animals to the slaughterhouse.

In the rats, cortisol concentration depended on the sequence of the removal of the animal from cages. Cortisol was significantly higher in rats, which were removed from cages the last.

The results which were obtained in model experiment on laboratory animals can be used in researches on cell immunity indices and stress hormones, such as cortisol, of farm animals for increasing their organism resistance and correction of their pre-slaughter stress.

Received 30 June 2018 Accepted 30 July 2019

\section{References}

1. Agnes F, Sartorelli P, Abdi BH, Locatelli A. Effect of transport loading or noise on blood biochemical variables in calves. Am J Vet Res. 1990; 51: 1679-81.

2. Azarova TO, Osipova LL, Zajcev SJu. Dinamika stress-assotsiirovannykh gormonov i pokazatelei antioksidantnoi zashchity $u$ molodnyaka krossa "Sheiver belyi". Ptitsa i ptitseprodukty. 2013; 1: 25-9. Russian.

3. Balcombe J, Barnard N, Sandusky C. Laboratory routines cause animal stress. Contemporary topics in laboratory animal science. 
American Association for Laboratory Animal Science. 2004; 43(6): 42-51.

4. Cannon WB. 1927. The James-Lange theory of emotions: a critical examination and an alternative. Am J Psychol. 1927: 39: 106-24.

5. Council Directive 2010/63/EU of 22 September 2010 on the protection of animals used for scientific purposes. Official Journal of the European Communities. 2010; L 276: 79-33.

6. Costa LN. Short-term stress: the case of transport and slaughter. Ital J Anim Sci. 2009; 8(1): 241-52.

7. Dokmanović $\mathrm{M}$, Velarde A, Tomović V, Glamočlija N, Marković R, Janjić J, Baltić MŽ. The effects of lairage time and handling procedure prior to slaughter on stress and meat quality parameters in pigs. Meat Sci. 2014; 98(2): 220-6.

8. European convention for the protection of vertebrate animals used for experimental and other scientific purposes. Council of Europe, Strasbourg, 1986:53 p.

9. Ferguson DM, Warner RD. Have we underestimated the impact of pre-slaughter stress on meat quality in ruminants? Meat Sci. 2008; 80(1): 12-9.

10. Frolov BA, Afonina SN, Meyerson FH. Role ratio cAMP/gTsMF post-stress activation in the primary immune response. Path Physiol Exp Therap. 1985; 5: 23-6. Russian.

11. Gerasimenko SS, Golovach AV, Erina AM. Statistics: Textbook. Kiev: KNEU. 2000; 1103. Ukrainian.

12. Gibson M, Norman RL. Shipping stress and social status effects on pig performance, plasma cortisol, natural killer cell activity, and leukocyte numbers. J Anim Sci. 1993; 71: 888-96.

13. Gispert M, Faucitano L, Oliver MA, Guardia MD, Coli C, Siggens K, Harvey K, Diestre A. A survey of pre-slaughter conditions, halothane gene frequency in five Spanish pig commercial abattoirs. Meat Sci. 2000; 55: 97-106.

14. Grabovskyi SS. Natural origin immunomodulators influence on cellular immunity indices and cortisol level in rats' blood at pre-slaughter stress. Studia Biologica. 2014; 8(1): 93-102. Ukrainian.

15. Grabovskyi S, Grabovska O. Natural origin immunomodulators influence on protein fractions, cortisol content in rabbits' blood under stress. Melitopol Biological Bulletin. 2015; 5(2): 93-102. Ukrainian.

16. Gray JA. The psychology of fear and stress. Weidenfeld and Nicolson. 1971; 256 p.

17. Haus E. Chronobiology in the endocrine system. Adv Drug Deliv Rev. 2007; 59: 985-1014.

18. Ibragimova LL, Ismagilova ER. The use of homeopathic medication "Fospasim" to enhance the adaptive capacity of rabbits during transport. Basic Res. 2013; 8(2): 376-9. Russian.

19. Kuzmenko EV, Nikiforov NA, Ivanenko MO. Phagocytic activity of peripheral blood neutrophils in rats with different responses to stress. News Harkiv Nationality University named after VN Karazina. Seriya: Biology. 2010; 11(905): 173-7. Russian.

20. Kim YHB, Warner RD, Rosenvold K. Influence of high pre-rigor temperature and fast $\mathrm{pH}$ fall on muscle proteins and meat quality: a review. Anim Prod Sci. 2014; 54(4): 375-95.

21. Lynn SE, Breuner CW, Wingfield JC. The effects of short-term fastingon activity, corticosterone, and corticosterone binding globulin in amigratory songbird, Gambel's white-crowned sparrow (Zonotrichia leucophrys gambelii). Horm Behav. 2003; 43: 150-7.

22. Linkowski P, Van Onderbergen A, Kerkhofs M, Bosson D, Mendlewicz J, Van Cauter E. Twin study of the 24-h cortisol profile: evidence for genetic control of the human circadian clock. Am J Physiol. 1993; 264(2): 173-81.

23. Malisch JL, Satterlee DG, Cockrem JF. How acute is the acute stress response? Baseline corticosterone and corticosteroid-binding globulin levels change $24 \mathrm{~h}$ after an acute stressor in Japanese quail. Gen Comp Endocr. 2010; 165(2): 345-50.

24. Marti O, Martin M, Gavalda A. Inhibition of corticosteroid-binding globulin caused by 
a severe stressor is apparently mediated by the adrenal but not by glucocorticoid receptors. Endocrine. 1997; 6: 159-64.

25. Minni AM, Dorey R, Piérard C. Critical role of plasma corticosteroid-binding-globulin during stress to promote glucocorticoid delivery to the brain: impact on memory retrieval. Endocrinology. 2012; 153(10): 4766-74.

26. Mormont MC, Waterhouse J. Contribution of the rest-activity circadian rhythm to quality of life in cancer patients. Chronobiol Int. 2002; 19: 313-23.

27. Official Journal of the European Union L276/33. Directive 2010/63/EU of the European Parliament and of the Council of 22 September 2010 on the protection of animals used for scientific purposes. 86/609/EC. 20.10.2010.

28. Panchenko LL. Stress: a reader. Vladivostok: Mor. state. University Press, 2003; 120 p. Russian.

29. Pica S, Mitani J. Referential gestural communication in wild chimpanzees (Pan troglodytes). Curr Biol. 2005; 16(6): 191-2.

30. Price DA, Close GC, Fielding BA. Age of appearance of circadian rhythm in salivary cortisol values in infancy. Arch Dis Child. 1983; 58(6): 454-6.

31. Qian X, Droste SK, Gutièrrez-Mecinas M. A rapid release of corticosteroid-binding globulin from the liver restrains the glucocorticoid hormone response to acute stress. Endocrinology. 2011; 152(10): 3738-48.

32. Reznikov OG. Zagalni etychni pryncypy eksperymentiv na tvarynax. Pershyj nacionalnyj kongres z bioetyky. Endokrynologiya. 2003; 8(1): 145-2. Ukrainian.

33. Rich $\mathrm{T}$, Innominato PF, Boerner J, Mormont MC, Iacobelli S, Baron B, Lévi F. Elevated serum cytokines correlated with altered behavior, serum cortisol rhythm, and dampened 24-hour rest-activity patterns in patients with metastatic colorectal cancer. Clin Cancer Res. 2005; 11(5): 1757-64.

34. Rocha LM, Bridi AM, Foury A, Mormede P, Weschenfelder AV, Devillers N, Faucitano L.
Effects of ractopamine administration and castration method on the response to preslaughter stress and carcass and meat quality in pigs of two Pietrain genotypes. J Anim Sci. 2013; 91(8): 3965-77.

35. Segerstrom SC, Miller GE. Psychological stress and the human immune system: $a$ metaanalytic study of 30 years of inquiry. Psychol Bull. 2004; 130(4): 601-30.

36. Slocombe KE, Zuberbuhler K. Agonistic screams in wild chimpanzees (Pan troglodytes schweinfurthii) vary as a function of social role. J Comp Psychol. 2005; 119(1): 67-77.

37. Śmiecińska K, Denaburski J, Sobotka W. Slaughter value, meat quality, creatine kinase activity and cortisol levels in the blood serum of growing-finishing pigs slaughtered immediately after transport and after a rest period. Pol J Vet Sci. 2011; 14(1): 47-54.

38. Stahl SM. Stahl's essential psychopharmacology: neuroscientific basis and practical application. 3nd ed. Cambridge: Cambridge University Press, 2008; 1117 p.

39. Tinnikov AA. Responses of serum corticosterone and corticosteroid-binding globulin to acute and prolonged stress in the rat. Endocrine. 1999; 11: 145-50.

40. Vlizlo VV, Fedoruk RS, Ratych IB, Vishhur OI, Sharan MM, et al. Laboratory methods of investigation in biology, stock-breeding and veterinary: Reference Book; Edited by VV Vlizlo. Lviv, SPOLOM, 2012; 764 p. Ukrainian.

41. Wesoly R, Jungbluth I, Stefanski V, Weiler U. Pre-slaughter conditions influence skatole and androstenone in adipose tissue of boars. Meat Sci. 2015; 99: 60-7.

42. Zavy MT, Juniewicz PE, Philips WA, Von Tungeln DL. Effect of initial resistant, weaning and transport stress on baseline and ACTH-stimulated cortisol response in beef calves of different genotypes. Am J Vet Res. 1992; 53: 551-7.

43. Zhukov D. Hare as a symbol of highly adaptive strategies lurking. Fatherland Notes 2014; 3: 60. Russian. 
Stepan Grabovskyi, Oleksandra Grabovska, Viktoriia Havryliak, Liliia Kalachniuk, Alla Velyka

PRIEŠSKERDIMINIO STRESO İTAKA KORTIZOLIO IR ADRENOKORTIKOTROPINIO HORMONO KIEKIUI GYVULIŲ KRAUJYJE

Santrauka

Kortizolio ir adrenokortikotropinio hormono (AKTH), dar vadinamų streso hormonais, didesnè koncentracija kraujyje yra būdinga sergant ịvairiomis ligomis, taip pat esant streso būsenai. Straipsnyje pateikiami priešskerdimini stresą patiriančių laboratorinių gyvūnų (žiurkių) kortizolio, jaučių AKTH, šernų kortizolio ir AKTH lygio kraujyje rezultatai. Kortizolio lygis žiurkiu kraujyje priklausẻ nuo gyvūno paemimo iš narvo laiko: pirmụjų paimtų gyvūnų jis padidejjo beveik 1,5 karto $(p<0,01)$ ir beveik 5 kartus $(p<0,05)$ paskutiniujų. AKTH koncentracija jaučių kraujo plazmoje iki tyrimo (parengiamasis laikotarpis) buvo 1,3 karto mažesnè $(p \leq 0,01)$, palyginti su jo kiekiu prieš pat gabenimą i skerdyklą. Kortizolio ir AKTH kiekio pokyčiai šernų kraujo plazmoje buvo panašūs. Mūsų tyrimo rezultatai turètų paskatinti taikyti harmoninę adaptaciją mèsos pramonèje naudojamiems gyvuliams, kad būtų sumažintos neigiamos priešskerdiminio streso pasekmès.

Raktažodžiai: priešskerdiminis stresas, streso hormonai, žiurkès, veršeliai, paršai 